\title{
Early Differences in the Intensity of Alternate Bearing Among Selected Pistachio Genotypes
}

\author{
Craig E. Kallsen ${ }^{1}$ \\ University of California Cooperative Extension, 1031 S. Mt. Vernon Avenue, \\ Bakersfield, CA 93307
}

Dan E. Parfitt
Department of Plant Sciences, MS2, University of California, One Shields
Avenue, Davis, CA 95616

Brent Holtz

University of California Cooperative Extension, Madera County, 328 Madera Avenue, Madera, CA, 93637

Additional index words. alternate bearing index, biennial bearing, masting, Pistacia vera

\begin{abstract}
Alternate bearing (alternating years with high and low yields) is a prominent characteristic of 'Kerman' pistachio (Pistacia vera $\mathbf{L}$.), the primary California cultivar. The degree of alternate bearing is described by alternate bearing index values from 0 (identical yields every year) to 1 (complete alternate bearing). Two separate and replicated trials designed to evaluate selections from a breeding program were conducted in the southwest (Kern County) and northeast (Madera County) areas of the San Joaquin Valley of California. Yields from the scion genotypes 'Kerman', 'Golden Hills', 'Lost Hills', 'B5-8', and 'B19-1' on PG1 rootstock were measured from 5- to 9-year-old trees in Kern County and from 5- to 7-year-old 'Kerman', 'Golden Hills', 'Lost Hills', and 'B5-8' trees on PG1 and UCB1 rootstock in Madera County. In Kern County, average annual yields among genotypes varied from a low of 208 to a high of $5273 \mathrm{~kg} \cdot \mathrm{ha}^{-1}$. Differences in the alternate bearing indices among genotypes were significant and ranged from 0.10 for 'Lost Hills' to 0.80 for 'B19-1'. A similar pattern was observed for alternate bearing indices at the Madera County trial. In this younger trial, scion genotype had more influence on alternate bearing indices than did rootstock. Marked differences in the intensity of alternate bearing of young trees in these two trials suggest that alternate bearing might be amenable to selection in breeding programs. However, the observation that ' $\mathbf{B 5 - 8}$ ', with an alternate bearing index of 0.74 , varied significantly from its female parent 'Kerman' at 0.36 suggests that inheritance is complex.
\end{abstract}

Alternate bearing (alternating years with high and low yields) is a prominent characteristic of 'Kerman' Pistacia vera L., the primary California cultivar (California Pistachio Commission, 2006; Monselise and Goldschmidt, 1982). Generally, alternate bearing in pistachio is considered a negative economic characteristic. Alternate bearing is approximately synchronous throughout California so that most orchards are either in a high- or low-yield cycle in any given year. This synchronization causes an oversupply of nuts in the high-yield year and an undersupply in the low-yield year, which results in marketing difficulties and added costs of cold storage.

Received for publication 20 Mar. 2007. Accepted for publication 24 June 2007.

This research was carried out in part with funding from the California Pistachio Commission and assistance from Paramount Farming Company and S\&J Ranch.

${ }^{1}$ To whom reprint requests should be addressed. e-mail cekallsen@ucdavis.edu.
Progress has been made in understanding alternate bearing in 'Kerman' pistachio trees beginning with research by Crane and Nelson (1971). Nzima et al. (1997a, 1997b, 1999) cited numerous studies that indicated that developing inflorescences and nuts on shoots promote inflorescence bud abortion on the new shoot growth above the inflorescences. Thus, in heavy-bearing years, many inflorescence buds, which would produce next year's crop, are aborted resulting in the following year being low-bearing. Ferguson et al. (1995) found that mechanical removal of dormant inflorescence buds before the onbearing year mitigated alternate bearing. Carbohydrate availability related to crop load (Crane and Iwakiri, 1987; Crane and Nelson, 1972; Crane et al., 1973, 1976b; Nzima et al., 1997a, 1997b, 1999) and hormone concentrations (Crane et al., 1976b; Lovatt et al., 2006) have been shown to be involved in inflorescence bud abortion. However, the initiating physiological stimulus for alternate bearing in pistachio remains unresolved. Stevenson and Shackel (1998) suggested that alternate bearing in pistachio may, primarily, be a masting phenomenon. Masting is an ecological adaptation based on a tree switching from vegetative and reproductive carbohydrate partitioning for reasons other than resource (i.e., carbohydrate) limitation (Silvertown, 1980). Some adaptive ecological factors that could have a role in natural selection for masting were listed by Stevenson and Shackel (1998) as follows: satiating seed predators, optimizing vegetative and reproductive growth in a random weather environment, reducing competition between sibling trees, maximizing pollination success, and keeping canopy fruit load above a certain threshold to attract animal-dispersing agents. Stevenson and Shackel (1998) suggested that selecting a cultivar with continued high production each year should be physiologically possible if alternate bearing is not the result of limited carbohydrate availability.

The primary objective of this communication is to document differences in the intensity of early alternate bearing among pistachio genotypes. Also discussed are implications of differences in the intensity of alternate bearing among genotypes to physiological studies and breeding programs.

\section{Materials and Methods}

Two research trials were established for evaluating advanced selections from a breeding program with 'Kerman'. The first trial was established in northwestern Kern County near the town of Lost Hills, CA, in 1997 on a calcareous and boric Panoche clay loam soil and the second one in Madera County near Madera, CA, in 1999 on a neutral Hanford fine sandy loam soil. The Kern County trial was located on the west side of the San Joaquin Valley, whereas the Madera County trial was located on the east side. Both trials were planted at the same time that the surrounding commercial orchards were planted and were irrigated, fertilized, and pruned identically to the surrounding 'Kerman' trees. Trees in these orchards were irrigated with low-volume irrigation systems and pruned annually. Fertilizers containing nitrogen, phosphorous, potassium, and micronutrients were applied through the irrigation systems and sprayed foliarly based on leaf tissue analysis. In the Kern County and Madera County trials, trees were spaced 5.18 and $3.66 \mathrm{~m}$ apart within the row, respectively, and the distance between rows was 5.79 and $7.32 \mathrm{~m}$, respectively.

At the Kern County site, the trial consisted of nine female genotypes selected from a breeding program and Kerman. All were grafted on PG1 rootstock. Ten trees of a given genotype composed an experimental unit. Experimental units were organized in a design consisting of two completely randomized blocks with each block containing one replication of each experimental unit. The trial in Madera County was also composed of nine selected female genotypes and Kerman in two completely randomized blocks. Like in Kern County, each experimental unit consisted of 10 trees of a given genotype. 
However, each experimental unit of 10 trees was further split by rootstock with five trees of a given genotype on PG1 and five of the same genotype on UCB1 rootstock. In both trials, the female genotypes within the test plots were pollinated by 'Peters' and 'Randy' males.

Yields were expressed as California Pistachio Commission (CPC)-assessed yield (California Pistachio Commission, 1990). California Pistachio Commission-assessed yield is adjusted to $5 \%$ moisture and includes the weight of edible, split nuts containing kernels, shelling stock (both kernels and shells), and unsplit nuts containing kernels. Culls such as nuts with insect damage, dark stains, adhering hulls, and other rejects are not included in CPC-assessed yield determinations.

Trees were harvested manually during the first 3 years that harvestable yields were produced and mechanically in subsequent years. Fresh weight yields were measured in the field with a calibrated commercial scale. Two or three (depending on the year) $9.1-\mathrm{kg}$ subsamples were removed at harvest from the fresh weight yields of each experimental unit (i.e., each replicate of given genotype) in Kern County or split experimental unit (i.e., within each replicate of a given genotype on a given rootstock) in Madera County. These subsamples were transported to a commercial huller for evaluation. At the huller, each subsample was weighed fresh, hulled, dried, adjusted to $5 \%$ moisture, and evaluated by inspectors trained by the U.S. Dept. of Agr. Evaluations consisted of quantifying the percentage of edible split nuts, shelling stock, closed-shell nuts, and culls. Subsample results were averaged and used to calculate the percentage by weight of CPC-assessed yield harvested from each experimental unit in Kern County or split experimental unit in Madera County.

The degree of alternate bearing was quantified using a method developed by Hoblyn et al. (1926) and reviewed by Pearce and Dobersek-Urbanc (1967) as follows:

$$
I=\frac{\sum \frac{\left|\mathrm{a}_{\mathrm{i}+1}-\mathrm{a}_{\mathrm{i}}\right|}{\mathrm{a}_{\mathrm{i}+1}+\mathrm{a}_{\mathrm{i}}}}{\mathrm{n}-1}
$$

where, $I=$ the alternate bearing index, $\mathrm{n}=$ number of years for which the alternate bearing index is calculated, and $a_{i}=$ yield in the ith year with $\mathrm{a}_{1}$ being the first year in which harvest occurred. I may vary between 0 (no alternate bearing) and 1 (complete alternate bearing).

Data were analyzed using analysis of variance and General Linear Model statistical packages in Statistica software (StatSoft, Tulsa, OK). For analysis purposes, $I$ values were transformed using arcsin of the square root of $I$. Standard $F$ tests in all analyses were used to determine significance of main plot, subplot, and interaction effects, where applicable. Means separation using Fisher's least significant difference (LSD) test was used only when $F$ tests indicated significance at $P \leq$ 0.05 (protected LSDS).
Tree trunk circumference has been correlated with yield parameters (Johnson and Weinbaum, 1987) and was measured in Sept. 2006 at both experimental sites $75 \mathrm{~cm}$ aboveground level (i.e., $\approx 20 \mathrm{~cm}$ above the graft union but below the first scaffolds).

\section{Results}

Results from five genotypes, 'Kerman', 'Golden Hills', 'Lost Hills', 'B19-1', and 'B5-8', were reported because complete data sets were available and they represented the range of the alternate bearing intensity observed.

In Kern County, average annual yields among genotypes varied from a low of 208 to a high of $5273 \mathrm{~kg} \cdot \mathrm{ha}^{-1}$. Marked differences in yield patterns among genotypes were obvious by the second year that yields were measured at the Kern County site (Fig. 1). Yields among the five genotypes were similar in the initial bearing year of 2002. 'Golden Hills' and 'Lost Hills' demonstrated higher yields in 2003 compared with 2002 in contrast to 'B19-1' and 'B5-8', which showed markedly lower yields. Both 'B19-1' and 'B5-8' exhibited severe alternate bearing in the first 4 or 5 years of production, whereas 'Lost Hills' showed minimal alternate bearing. The trial in Kern County provided a longer record of the alternate bearing habit for the evaluated genotypes than the Madera site; nevertheless, similar differences in alternate bearing developed among the cultivars in Madera County (Fig. 2). 'Kerman', the industry standard, typically shows annual increases in yield until the ninth or tenth year from planting in the southern San Joaquin Valley, when severe alternate bearing begins to develop. The substantial decline in the yield of 'Kerman' in 2006 probably indicated the beginning of a pronounced alternate bearing pattern (Fig. 1). Pistachio orchards on the west side of the San Joaquin Valley in California tend to reach full bearing earlier than on the east side and by 2004 trees were approaching full bearing in the Kern County trial (California Pistachio Commission, 2006).

Distinct differences in $I$ (the alternate bearing index) existed among the genotypes (Table 1). For the first 5 years of harvestable yields at the Kern County location, I ranged from a high value of 0.80 for 'B19-1' to a relatively low value of 0.10 for 'Lost Hills'. The alternate bearing indices calculated for each genotype, based only on the first three harvests in Kern County, were similar to those calculated for the first 5 years (Table 1). 'Kerman' had a low I score at the Madera County site because yield in the third year did not increase, whereas 'Lost Hills' and 'Golden Hills' yields increased as would be expected as the trees became larger (Table 2). The scion appeared to exercise more control over yield and alternate bearing than did the two rootstocks (PG1 or UCB1) in the Madera County results. Alternate bearing indices were different among genotypes, but the rootstock effect was not significant (Table 2 ). Crane and Forde (1976a) found differences in yield among trees on different rootstocks, but none of the rootstocks used in their study had Pistacia integerrima (J. L. Stewart ex. Brandis) heritage such as that existing in PG1 or UCB1.

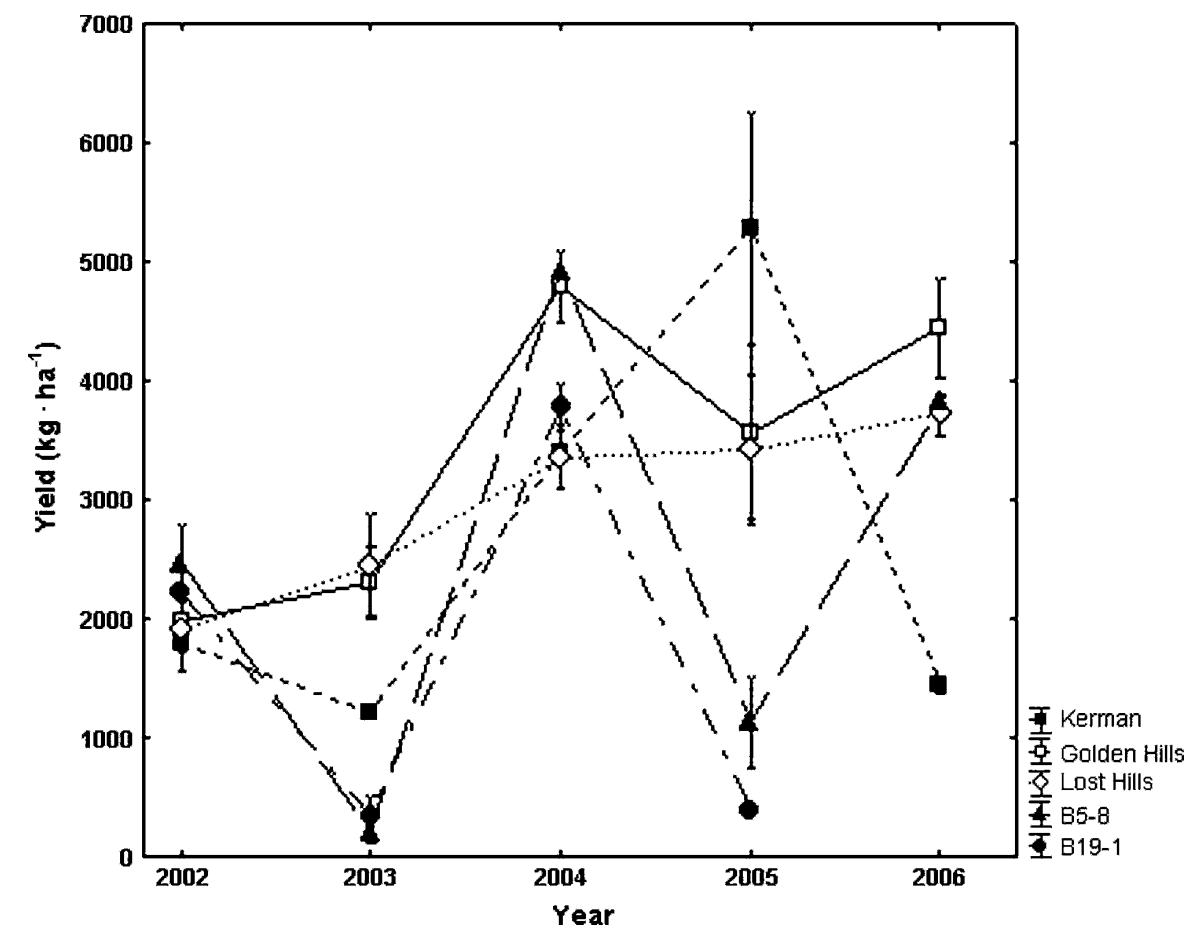

Fig. 1. Variation in California Pistachio Commission-assessed yield among five pistachio genotypes from 2002 (the first year of harvestable yield) through 2006 in Kern County. Vertical bars represent \pm SEM. 




Fig. 2. Variation in California Pistachio Commission-assessed yield among four pistachio genotypes from 2004 (the first year of harvestable yield) through 2006 in Madera County. Vertical bars represent \pm SEM.

Table 1. Alternate bearing indices $(I)$ calculated for Kerman, Golden Hills, Lost Hills, B5-8, and B19-1 genotypes on PG1 rootstock for two time periods in Kern County.

\begin{tabular}{|c|c|c|}
\hline Genotype & $\begin{array}{l}2002-2004 \\
\text { Years 5-7y }\end{array}$ & $\begin{array}{c}2002-2006^{z} \\
\text { Years 5-9 }\end{array}$ \\
\hline & \multicolumn{2}{|c|}{ Alternate bearing index } \\
\hline Kerman & $0.33 \mathrm{a}^{\mathrm{x}}$ & $0.36 \mathrm{~b}$ \\
\hline Golden Hills & $0.22 \mathrm{a}$ & $0.18 \mathrm{a}$ \\
\hline Lost Hills & $0.14 \mathrm{a}$ & $0.10 \mathrm{a}$ \\
\hline B5-8 & $0.89 \mathrm{c}$ & $0.74 \mathrm{c}$ \\
\hline \multirow[t]{2}{*}{ B19-1 } & $0.79 \mathrm{c}$ & $0.80 \mathrm{c}$ \\
\hline & \multicolumn{2}{|c|}{ Alternate bearing index } \\
\hline$P$ & & \\
\hline Genotype & 0.0025 & 0.0005 \\
\hline Block & NS & NS \\
\hline
\end{tabular}

${ }^{{ }^{2}}$ Years from which alternate bearing indices are calculated. B19-1 was not harvested in 2006 and its index is calculated from 2002-2005 only.

${ }^{y} \mathrm{Age}$ in years after planting of trees from which alternate bearing indices are calculated.

${ }^{x}$ Means within a column followed by the same letter are not significantly different based on Fisher's protected least significant difference (LSD) test at $P \leq 0.05$.

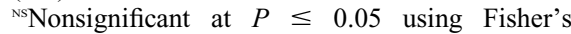
protected LSD.

Tree size appeared similar among genotypes throughout the experiment at each location. In 2006, tree-trunk circumferences were measured and were not different in Kern County and averaged $49.7 \mathrm{~cm}$. In Madera County, 'Golden Hills' had a smaller trunk circumference than 'Lost Hills' and 'B5-8' ( 39.2 versus 43.5 and $43.4 \mathrm{~cm}$, respectively). 'Kerman' was not different from the other genotypes at $39.4 \mathrm{~cm}$. intensity is heritable, the inheritance is probably complex. For example, 'Lost Hills', 'Golden Hills', and 'B19-1' had the same female parent but different male parents. 'B58 ' and 'Kerman' exhibited different alternate bearing patterns as well, yet 'Kerman' is the female parent of 'B5-8'. Heritability studies would be necessary to separate the variance associated with alternate bearing into that attributable to genotype and to environment.

The more uniform bearing of 'Lost Hills' and 'Golden Hills' suggests that inflorescence bud abortion does not occur on these genotypes to the same extent as 'B19-1' and 'B5-8' or, possibly, individual shoots still alternate bear within the canopy, but there are enough bearing and nonbearing stems in a canopy in any given year to maintain consistent cropping patterns. Further research identifying differences among these genotypes on how nuts are produced on individual shoots could increase the rate of progress in developing cultivars with reduced alternate bearing intensity.

The intensity of alternate bearing exhibited by 'B19-1' and 'B5-8' immediately on becoming reproductive, in marked contrast to 'Lost Hills', 'Golden Hills', and 'Kerman', should provide opportunities for studying the underlying physiological stimulus that initiates alternate bearing in pistachio. Plant physiological processes that could be compared among these genotypes include differences in: carbon fixation, metabolism, and allocation among plant organs; in plant hormone levels; winter chill requirements; and growth and yield response to other weatherrelated variables.

\section{Literature Cited}

California Pistachio Commission. 1990. United States standards for grades of pistachio nuts. California Pistachio Commission, Quality grades and handling guide. Fresno, CA.

California Pistachio Commission. 2006. California pistachio industry. Annu. Rpt. crop year 200506. p. $72-75$.

Crane, J.C., I. Al-Shalan, and R.M. Carlson. 1973. Abscission of pistachio inflorescence buds as affected by leaf area and number of nuts. J. Amer. Soc. Hort. Sci. 98:591-592.

Crane, J.C. and H.I. Forde. 1976a. Effects of four rootstocks on yield and quality of pistachio nuts. J. Amer. Soc. Hort. Sci. 101: 604-606.

Crane, J.C., P.B. Catlin, and I.M. Al-Shalan. 1976b. Carbohydrate levels in pistachio as related to alternate bearing. J. Amer. Soc. Hort. Sci. 101:371-374

The results demonstrate that pistachio cultivars may vary considerably in the intensity of alternate bearing exhibited during early reproductive years. These differences suggest that the intensity of alternate bearing may be amenable to selection in breeding programs. One reason that some genotypes used in this study were named and patented (i.e., 'Golden Hills' and 'Lost Hills'), whereas 'B19-1' and 'B5-8' were not, was the early alternate bearing patterns displayed in evaluation trials. If alternate bearing

Crane, J.C. and B.T. Iwakiri. 1987. Reconsideration of the cause of inflorescence bud abscission in pistachio. HortScience 22:13151316 .

Crane, J.C. and M.M. Nelson. 1971. The unusual mechanism of alternate bearing in pistachio. HortScience 6:489-490.

Crane, J.C. and M.M. Nelson. 1972. Effects of crop load, girdling, and auxin application on alternate bearing of the pistachio. J. Amer. Soc. Hort. Sci. 97:337-339.

Ferguson, L., J. Maranto, and R. Beede. 1995. Mechanical topping mitigates alternate bearing 
on 'Kerman' pistachios (Pistacia vera L.). Hort. Sci. 30:1369-1372.

Hoblyn, T.N., N.H. Grubb, A.C. Painter, and B.L. Wates. 1926. Studies in biennial bearing. I. J. Pomology Hort. Sci. 14:39-76.

Johnson, R.S. and S.A. Weinbaum. 1987. Variation in trees size, yield, cropping efficiency, and alternate bearing among 'Kerman' pistachio trees. J. Amer. Soc. Hort. Sci. 112: 942-945.

Lovatt, C.J., H. Daoudi, and L. Ferguson. 2006. Efficacy of foliar-applied cytokinins and nitrogen to increase floral bud retention and to reduce alternate bearing of pistachio. Acta Hort. 727:353-364.
Monselise, S. and E. Goldschmidt. 1982. Alternate bearing in fruit trees. Hort. Rev. (Amer. Soc. Hort. Sci) 4:128-173.

Nzima, M.D.S., G.C. Martin, and C. Nishijima. 1997a. Seasonal changes in total nonstructural carbohydrates within branches and roots of naturally 'off' and 'on' 'Kerman' pistachio trees. J. Amer. Soc. Hort. Sci. 122:856-862.

Nzima, M.D.S., G.C. Martin, and C. Nishijima. 1997b. Leaf development, dry matter accumulation, and distribution within branches of alternate-bearing 'Kerman' pistachio trees. J. Amer. Soc. Hort. Sci. 122:31-37.

Nzima, M.D.S., G.C. Martin, and C. Nishijima. 1999. Effect of fall defoliation and spring shading on shoot carbohydrate and growth parameters among individual branches of alternate bearing 'Kerman' pistachio trees. J. Amer. Soc. Hort. Sci. 124:52-60.

Pearce, S.C. and S. Dobersek-Urbanc. 1967. The measurement of irregularity in growth and cropping. J. Hort. Sci. 42:295-305.

Silvertown, J. 1980. The evolutionary ecology of mast seeding in trees. Biol. J. Linnean Soc. 14:235-250.

Stevenson, M.T. and K.A. Shackel. 1998. Alternate bearing in pistachio as a masting phenomenon: Construction cost of reproduction versus vegetative growth and storage. J. Amer. Soc. Hort. Sci. 123:1069-1075. 